\title{
Hypopigmentation in vespertilionid bats: the first record of a leucistic soprano pipistrelle Pipistrellus pygmaeus
}

\author{
Adrià LóPez Baucells ${ }^{1 *}$, Maria Mas ${ }^{1}$, Xavier Puig-Montserrat $^{1,2}$ \& Carles Flaquer $^{1}$ \\ ${ }^{1}$ Granollers Museum of Natural Sciences, Bat Research Group, \\ Av. Francesc Macià 51, 08402 Granollers, Catalonia. \\ ${ }^{2}$ Galanthus Association. Carretera de Juià, 46 - 17460 Celrà, Catalonia \\ *Corresponding author e-mail: adria.baucells@gmail.com \\ DOI:_http://dx.doi.org/10.14709/BarbJ.6.1.2013.09
}

Spanish title: Hipopigmentación en vespertilionidos: primera cita de murciélago de Cabrera (Pipistrellus pygmaeus) leucístico

\begin{abstract}
Albinism and leucism are commonly confused in the literature. Despite the fact that these congenial disorders affect only a small proportion of bat populations, they seem to be widely spread since reports of affected bats are found from over the world. In this communication we report for the first time a leucistic Pipistrellus pygmaeus (Leach 1825). It was captured in the Ebro Delta Natural Park (Iberian Peninsula) in a biological field station near a wetland with rice paddies, where over 100 bat boxes are deployed to monitor bat populations. The individual had whitish fur over the whole of its body (dorsal and ventral parts); nevertheless its eyes and wing membranes had normal pigmentation. Although an albino P. pygmeaus has been reported from Spain, this represents the first report of leucism in this species.
\end{abstract}

Keywords: albinism, Catalunya, chromatic aberration, leucism, pigmentation.

\section{INTRODUCTION}

Albinism and leucism should not be confused and, like other alterations such as melanism, are in fact different types of amelanisms that affect pigmentation and individual colouration. Albinism is defined as a hereditary lack of pigmentation due to a mutation that causes the loss of an enzyme involved in melanin synthesis; on the other hand, leucism is a pigmentation deficiency localized in the integument (Roncancio \& Ramírez-Chaves 2008; Marin-Vasquez et al. 2010; Idoeta et al. 2011, García-Morales et al. 2012, Treitler et al. in press). The main external difference between these two chromatic aberrations is the extent of the affected area: in albinism the whole body (including membranes) is affected and eyes are red due to exposed capillary vessels, while in case of leucism discolouration is partial and there are generally white patches of fur (but no red eyes). It is important to note that not all leucistic specimens are caused by genetic mutations (Acevedo et al. 2009) and that leucism has on occasions been confused with examples of partial albinism (Watkins 1903, Harada et al 1991, Boada \& Tirira 2010).

Both type of amelanisms have been reported in taxonomic groups worldwide including amphibians (Mitchell \& Church 2002; Teixeira et al. 2009), reptiles (Rocha 2010), birds (Jehl 1985; Bried et al. 2005) and mammals (Uieda 2000; Acevedo \& Aguayo 2008; Marin-Vasquez et al. 2010, Treitler et al. in press). In the case of bats, the number of reports is low, probably due to the lack of attention this group has received compared to other vertebrates and thus only few studies and/or scientific communications can be found regarding bat leucism and albinism (Uieda 2000). 
Different hypotheses have been posed regarding the possible effect of these chromatic aberrations on the fitness and survival of affected individuals. Although some authors hypothesise that whitish colouration has a negative effect on an animal's fitness (Marín-Vasquez 2010), the predominant approach is that neither albinism nor leucism affect survival rates (Rees 2004; Krecsák 2008; Sánchez-Hernández et al. 2010). Cases of colour pigmentation deficiencies have been reported in many tropical bat species (Gundlach 1877, Glass 1954, Herreid 1960, Bárquez et al 2003, Sodre 2004, Boada et al 2010, GarcíaMorales 2010) and in a number of temperate species (Howell 1980, Haensel 1993, Bartonika and Burick 2007, Gaisler 2011) from all continents.

Although little information exists in the Iberian Peninsula concerning either albino or leucistic individuals, albinism has previously been reported in Pipistrellus pygameus (Alcalde 2009), one of the commonest bat species in the region, and noted in other species via personal comments and local reports (e.g. Tadarida teniotis in Balmori 2012).

In this communication we report the first case of leucism in Pipistrellus pygmaeus in the Iberian Peninsula in an individual captured in the Ebro Delta (E Iberian Peninsula) and summarize current knowledge of the incidence of this type of colour alteration in the region.

\section{Material ANd Methods}

Bat-box monitoring has been conducted every year since 1999 in the Ebro Delta Natural Park Biological Station located on Buda Island $\left(0^{\circ}\right.$ 50' E, 40 42' N; Catalonia, NE Iberia). The Ebro Delta Natural Park is one of the most important wetlands in Europe and much of its surface area is covered by rice paddies and natural habitats (saltmarshes, reed beds, lagoons, etc.). Scattered trees (Eucalyptus globulus and Washingtonia filifera) and a few buildings are also present. Mean annual temperatures range between $17-18^{\circ} \mathrm{C}$, mean annual precipitation between $500-550 \mathrm{~mm}$, and mean annual evapotranspiration between 855-997 $\mathrm{mm}$ (mesothermic) in what is essentially a semiarid climate.

Bat research has been conducted in this area since 1999 (Flaquer et al 2005, Flaquer et al 2006)

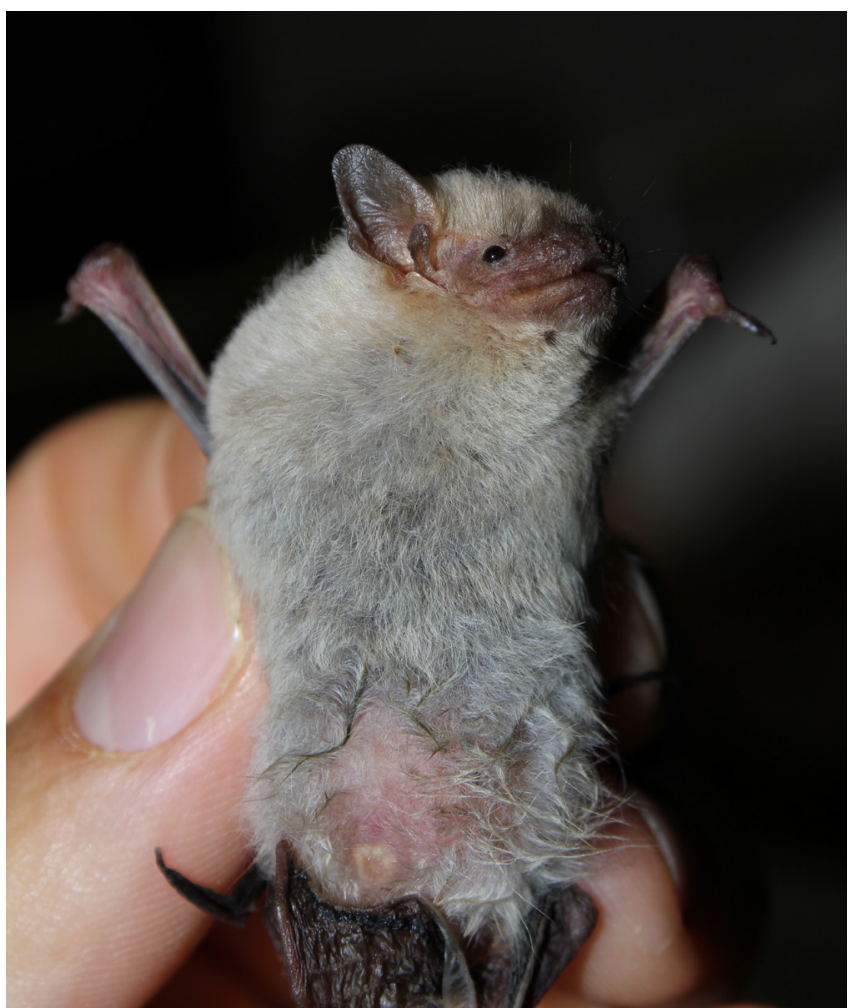

Fig. 1 Leucistic Pipistrellus pygmaeus: Whitish body colouration.

as part of a bat-monitoring and -conservation strategy promoted by the Natural Park. In 199969 bat boxes were placed on Buda Island within the framework of a European Life project. The boxes were rapidly colonized in the following years and by summer 2006 hosted around 3,000 individuals (Flaquer et al 2006). All bat boxes are regularly inspected during spring and autumn as part of a new project.

The bat boxes are made of pinewood $(20 \mathrm{~mm}$ thick, $100 \times 190 \times 200 \mathrm{~mm}$ ), with a slit size of 15 $\mathrm{mm}$ and a landing platform of about $100 \mathrm{~mm}$. While some have only one cavity, others are split into two compartments. All bat boxes were placed approximately $4 \mathrm{~m}$ above ground level.

\section{ReSUlts AND DiscuSSION}

In all, 1,685 Pipistrellus pygmaeus have been captured in the Ebro Delta using mist-nets and inspections of bat boxes. Of all the $P$. pygmaeus captured since 2000, only one individual (captured on 30 October 2012) has had atypical leucistic coloration (Fig. 1). 
P. pygmaeus is a very small bat species with a short pale snout and short pale ears. Commonly, this species varies from sandy-red to brownish in colouration, being slightly paler on its ventral surface (Dietz 2009). Some facial regions can be slightly more yellowish/orangey and overall the body is more greyish in juveniles than in adults. Generally, this species has a lighter skin colour than other Pipistrellus. The hair on the uropatagium is similar to that of $P$. nathusii, but extends substantially further than on $P$. pipistrellus (Dietz 2009).

The captured leucistic specimen had abnormal whitish pigmentation on the whole of its body, but without any patchiness; its eyes, wings and skin were normally coloured, as is typically found in leucistic individuals. The individual in question was an adult female weighing $7.1 \mathrm{~g}$ with both the normal wing venation and colour for the species, as well as size within the known range (forearm: $32.4 \mathrm{~mm}$ ). It showed no evidence of mating activity and, given that it was not collected as a voucher specimen, it was released at the same place as capture without being banded or microchipped as other individuals are.

The individual was caught in a bat box with at least 30 other bats, all with normal pigmentation. No different behaviour was detected when checking the box, either during handling or manipulation. Although albinism has been reported in this species from the Iberian Peninsula (Alcalde 2009), our finding represents the first report of leucism for this species worldwide. Besides the report for Pipistrellus pygmaeus, there are no other official records of abnormal pigmentations in bats from the Iberian Peninsula. However, according to some reports amelanism has been detected in other species (for example, an albino Tadarida teniotis; Balmori 2012).

As can be seen from the most recent published revision of albinism in bats (Uieda 2000), this type of amelanism occurs more frequently in Vespertilionidae than in other families, probably due to the fact that most effort in bat research has historically been carried out with this taxonomical group. Within the genus Pipistrellus, chromatic aberrations have been found in at least three different species: P. subflavus (albinism reported from Ohio, Bures 1948; leucism from Ohio, Goslin 1947; and melanism from Vermont, Osgood 1938), P. pipistrellus (Cerveny 1977, Haensel 1972) and

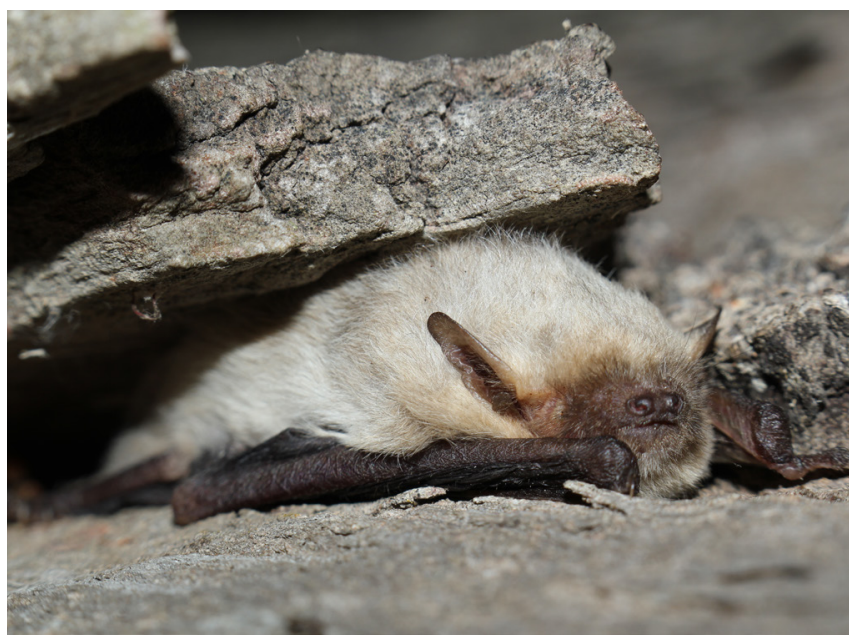

Fig. 2 Leucistic Pipistrellus pygmaeus: Natural refuges in the area with the leucistic individual (mimetic coloration).

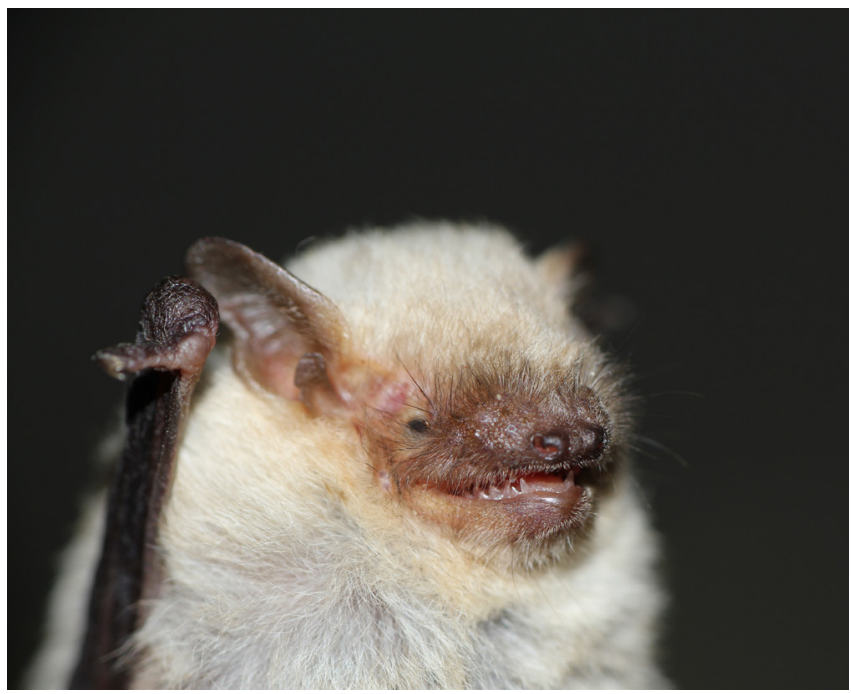

Fig. 3 Leucistic Pipistrellus pygmaeus: Whitish fur on the face, but dark, normally pigmented skin.

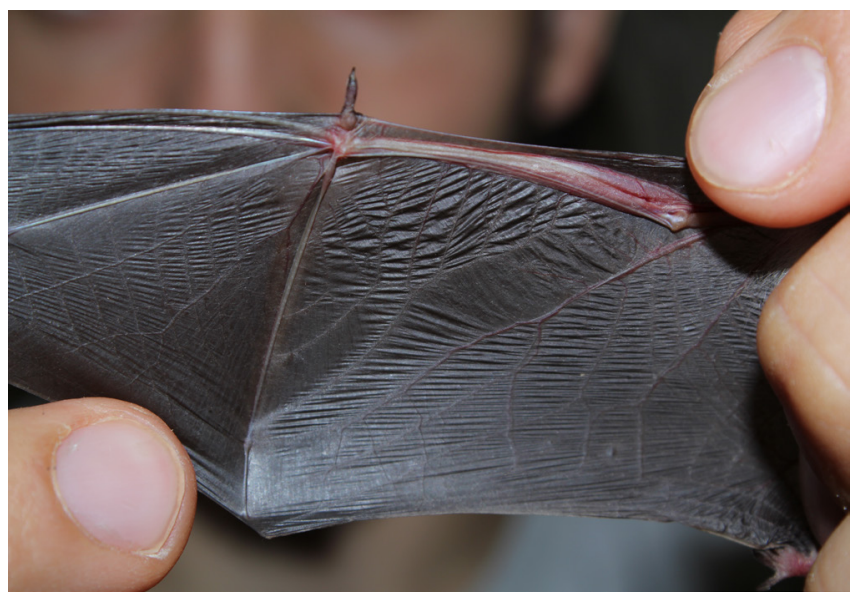

Fig. 4 Leucistic Pipistrellus pygmaeus: black, normally coloured wings with normal venation.

P. pygmaeus (albinism reported from Lodosa, Spain, Alcalde 2009).

The possible detrimental effect of albinism and leucism on bat survival rates and fitness has 


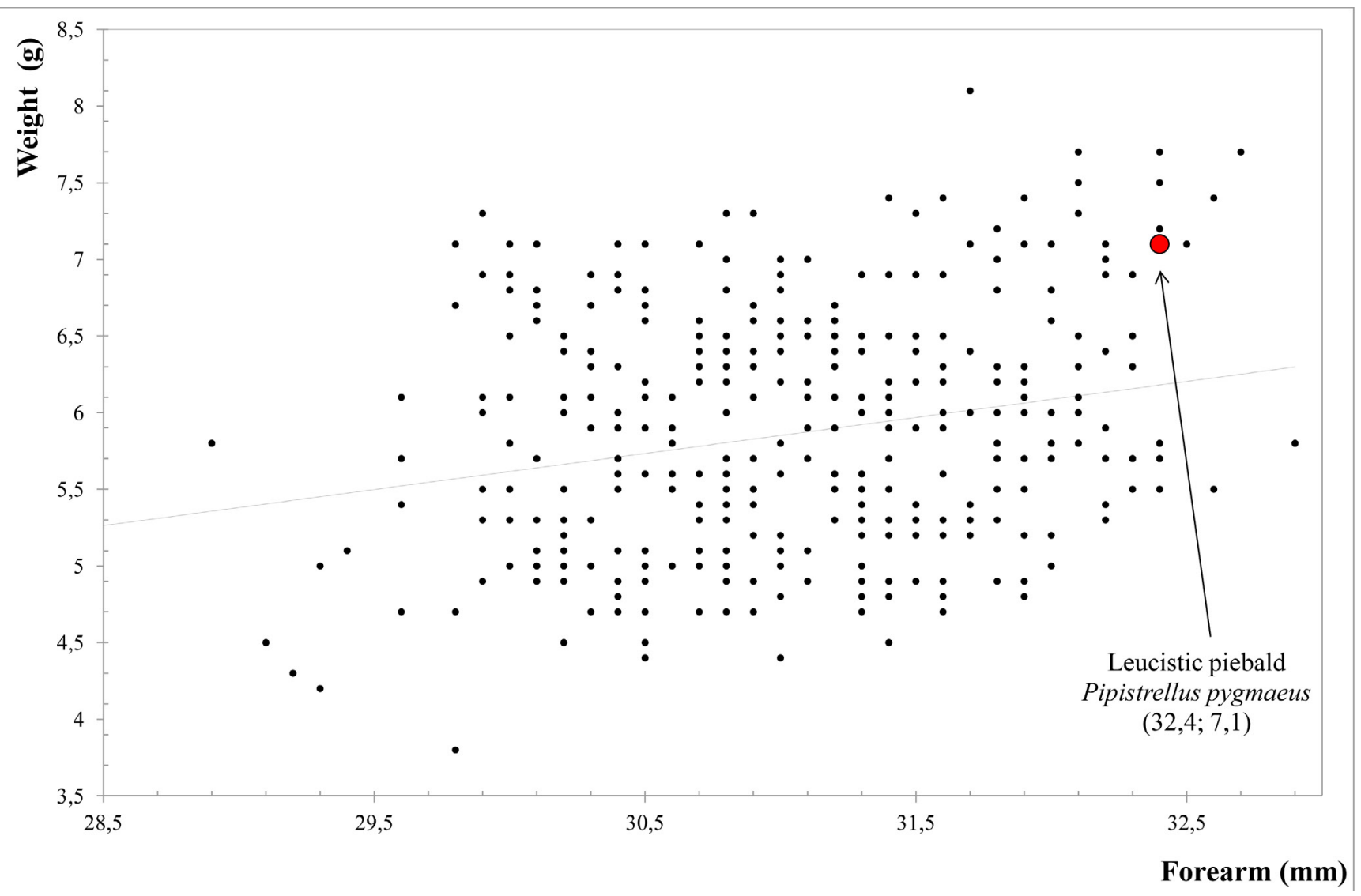

Fig. 5 Body condition of Pipistrellus pygmaeus (only captures in October 2011). The red spot corresponds to the leucistic P. pygameus.

been considered and discussed in several papers in which the first reports of albinism for species are usually given (Uieda 2000, Caro 2005). Although most publications assert that these chromatic aberrations have no negative effects on bats (Rees 2004; Krecsák 2008; Sánchez-Hernández et al. 2010), others maintain the opposite (MarínVásquez 2010). Unfortunately, to date no solid evidence exists to support either one of these theories.

Certain bat species such as Ectophylla alba (Allen, 1892) and Diclidurus albus (WiedNeuwied, 1820) have evolved complete white fur or partially white fur (e.g. Micronycteris carrikeri; Allen, 1910). Aside from these tropical species, a geographically and genetically closer example from the genus Pipistrellus is found in North Africa: the natural snow-white ventral fur that contrasts greatly with the grey-brown back of the poorly known Pipistrellus rueppelli (Fisher, $1829)$ is an example of the positive selection of white fur. This bat's range extends relatively near to the Iberian Peninsula and has been recorded in the Sahara from Sudan to Senegal, as well as from Angola, Botswana, north-west Morocco and the Arabian Peninsula. The presence of white fur on similar species suggests that the effects on bat survival of these chromatic aberrations may be of very little - if any - importance.

We also compared the body condition of the hypopigmented bat with other captures from the same day and no lower values were detected (Fig. 2). Two individuals of this species with very small white patches on their backs had previously been captured. However, the real frequency of occurrence of these mutations remains unknown. It is probable that nocturnal animals that roost in boxes protected from predators do not suffer detrimental effects from whitish colouration given that they are not more easily detected by predators. Nevertheless, the singular cases presented here do not provide enough information on the consequences of hypopigmentation in bats to draw conclusions regarding the extent of this effect.

\section{Conchusion}

In this note we report a leucistic Pipistrellus pygmaeus (Leach 1825) captured in a bat box in the Ebro Delta Natural Park (Iberian Peninsula). Although a previous case of albinism has been 
recorded in Spain, this record represents the first report of leusicm in this species worldwide. Taking into consideration all the information regarding amelanisms in bats and the presence of white fur on several species, we consider that it would be speculation to conclude that the existence of hypopigmentation has detrimental or positive effects on individuals. Bearing in mind the lack of chromatic aberrations reported from the Iberian ninsula, we encourage researchers to publish findings to enable us to improve knowledge of how these mutations affect bat survival and behaviour.

\section{ACKNOWLEDGEMENTS}

We would like to thank Francesc Vidal and Antoni Curcó for thier help with the permits and logistics in the Ebro Delta Natural Park, Xavier Porres, Xavier Llambrich, Miquel Àngel and Laura Martínez, for their continuous help and support during the fieldwork, and Antoni Arrizabalaga for his many contributions to the Bat Research Group in the Museum of Granollers.

Financial support was provided by the Ebro Delta Natural Park, Avid Microchips España and Barcelona Zoo. This study was ethically cleared; scientific permits were issued by the Servei de Fauna de la Generalitat Catalunya.

\section{REFERENCES}

Acevedo, J. \& Aguayo, M. 2008. Leucistic South American sea lion in Chile, with a review of anomalously color in otariids. Revista de Biología Marina y Oceanografía 43(2): 413417. DOI: http://dx.doi.org/10.4067/S0718$\underline{19572008000200017}$

Acevedo J., Torres, D. \& Aguayo-Lobo, A. 2009. Rare piebald and partially leucistic Antarctic fur seals, Arctocephalus gazella, at Cape Shirreff, Livington Island, Antarctica. Polar Biology 32: 41-45. DOI: https://dx.doi. org/10.1007/s00300-008-0500-6

AlCALDE, J. T., 2009. Myotis alcathoe Helversen \& Heller, 2001 y Pipistrellus pygmaeus (Leach, 1825), nuevas especies de quirópteros para Navarra. Munibe (Ciencias Naturales-Natur Zientziak) 57: 225-236.
Allen, H. 1892. Description of a new genus of phyllostome bats. Proceedings of the United States National Museum 15(913): 441-442.

Allen, H. 1910. Bull. Amer. Mus. Nat. Hist., XXVIII, art. 12, p. 147.

BALMORI, A. 2012. Murciélago rabudo - Tadarida teniotis. En: Enciclopedia Virtual de los Vertebrados Españoles. Salvador, A., Cassinello, J. (Eds.). Museo Nacional de Ciencias Naturales, Madrid.

Bárquez, R. M., Carrizo, L. V., Ferro, L. I., Flores, D. A., Mollerach, M. I., SÁNChez, M. S., \& García-Lopez, A. P. 2003. Primer caso de albinismo total para Sturnira erythromos (Tschudi, 1844)(Chiroptera: Phyllostomidae). Chiroptera Neotropical 9. 1-2 166-169.

Bartonika, T. \& Burick, Z. 2007. Nález albinotických vrápencu malých (Rhinolophus hipposideros) v Hrubém Jeseníku. Vespertilio 11: 167-169.

BoAda, C. \& Tirira, D. G. (2010) First record of partial albinism (leucism) in Carollia perspicillata (Phyllostomidae) in Ecuador. Chiroptera Neotropical 16 (2): 755-757.

Bried, J., Fraga, H. Calabuig-Miranda, P. \& Neves, V. C. 2005. First two cases of melanism in Cory's Shearwater Calonectris diomedea. Marine Ornithology 33: 19-22.

Bures, J. A. 1948. Mammals of a limited area in Maryland: Maryland Naturalist 18: 59-72.

CARO T. 2005. The adaptive significance of coloration in mammals. BioScience 55:125136. DOI: https://dx.doi.org/10.1641/00063568(2005)055[0125:TASOCI]2.0.CO;2

Cerveny, J. \& Burger, P. 1977. Nalez albinotickeho netopyra vodniho, Myotis daubentoni (Kuhl, 1819) na Sumave.

Dietz, C., Nill, D., von Helversen, O., Lina, P. H. C. \& Hutson, A. M. 2009. Bats of Britain, Europe and Northwest Africa. London : A\&C Black. 400p 
Flaquer, C., Ruiz-Jarillo, R., Torre, I. \& Arrizabalaga, A. 2005. First resident population of Pipistrellus nathusii (Keyserling and Blasius, 1839) in the Iberian Peninsula. Acta Chiropterologica, 7(1): 183188. DOI: http://dx.doi.org/10.3161/17335329(2005)7[183:FRPOPN]2.0.CO;2

Flaquer, C., TORRe, I. \& Luís-JARILlo, R. 2006. The value of bat-boxes in the conservation of Pipistrellus pygmaeus in wetland rice paddies. Biological Conservation 128(2): 223-230. DOI: https://dx.doi.org/10.1016/j. biocon.2005.09.030

Gaisler, J., Kovarik, M. \& Stefka, L. Two unusual records of the lesser horseshoe bat (Rhinolophus hipposideros) in the Moravian Karst (Czech Republic). Hystrix, the Italian Journal of Mammalogy 22 (1): 73-79.

García-Morales, R., Gordillo-Chávez, E. J., \& Bello-Guitérrez, J. 2010. Primer registro de albinismo en Glossophaga soricina (Phyllostomidae) en México. Chiroptera Neotropical 16(2): 743-747.

García-Morales, R. Tejada Duran, D., Ávila Gómez, E. S., Moreno, C. E. \& Akmentins, M.S. 2012. Registro de leucismo en Sturnira ludovici y Artibeus jamaicensis (Phyllostomidae) en México. Chiroptera Neotropical 18(1): 1101-1105.

Glass, B. P. 1954. Aberrant Coloration in Tadarida Mexicana. American Midland Naturalist 52 (2): 400-402.

GosLIN, R. 1947. Abat with white wing tips. Journal of Mammalogy 28:62. DOI: http://dx.doi. org/10.1093/jmammal/28.1.62

GuNDLACH, J. 1877. Contribución a la mamología cubana. Imprenta G: Montiel, La Habana.

Haensel, J., Ittermann, L. \& Näfe, M. 1993. Flavismus bei einem Braunen Langohr (Plecotus auritus), erhebliche Farbaufhellung bei einem Grauen Langohr (Plecotus austriacus). Nyctalus (Neue Folge), 4(5): 465-468.
Harada, M., SaWADA, I. \& Aso, K. 1991. Albinism in the Japanese Large-footed Bat Myotis macrodactylus. J. Mamm. Soc. Japan 16 (1): 37-39.

Howell, K. M. 1980. Abnormal white colouration in three species of insectivorous African bats. Journal of Zoology. 191: 424-427. DOI: https://dx.doi. org/10.1111/j.1469-7998.1980.tb01472.x

Idoeta, F. M., De Santis, L. J. M. \& Bárquez R. M. 2011. Leucismo en Eptesicus furinalis (d'Orbigny y Gervais, 1847) (Chiroptera: Vespertilionidae) en la provincia de Corrientes, Argentina. Chiroptera Neotropical 17(2): 985-988.

JEHL, J.R. 1985. Leucism in eared grebes in western North America. The Condor 87: 439-441.

KrecsáK, L. 2008. Albinism and leucism among European Viperinae: A review. Russian Journal of Herpetology 15(2): 97-102.

MARÍN-VASQUeZ,A.,ORTEGA-RINCÓN,M.,RAMÍREZChaves, H. E. 2010. Records of leucism in three species of Colombian bats: Carollia brevicauda, Artibeus jamaicensis and Lophostoma silvicolum (Phyllostomidae). Chiroptera Neotropical 16 (2): 706-709.

Mitchell, J. C. \& Church, D. R. 2002. Leucistic Marbled Salamanders (Ambystoma opacum) in Virginia. Banisteria 20: 67-69.

OsGood, F. L. 1938. The Mammals of Vermont. Journal of Mammalogy 19 (4): 435-441. DOI: http://dx.doi.org/10.2307/1374228

ReEs, P. A. 2004. Are white lions ambassadors or conservation white elephants? International Zoo News 51: 484-489.

Rocha, R. \& Rebelo, R. 2010. First record of a piebald Selvagens Gecko Tarentola boettgeri bischoffi (Squamata: Gekkonidae). Herpetology Notes 3: 361-362.

Roncancio, N. \& RamíRez-Chaves, H. E. 2008. Registro de leucismo en Sturnira erythromos en los Andes centrales de Colombia. Chiroptera Neotropical 14(2): 412-414. 
SÁNCHEZ-HernÁNDEZ,C.,Romero-AlmaraZ,M.L., TabOAdA-SALgado,A.,AlmaZÁN-CATALÁNJ. A., SChNell, G. D. \& SÁNChEZ-VÁzQUEZ, L. 2010. Five albino bats from Guerrero and Colima, Mexico. Chiroptera Neotropical 16(1): 541-545.

Sodre, M. M. UiedA, W. \& BALdim, M. 2004. First record of albinism in the bat Eumops glaucinus (Molossidae) from southeastern Brazil. Chiroptera Neotropical 10(1-2): 200201.
Teixeira, J., Fráguas, B. \& Alexandrino, J. 1999. A larval albino of the golden-striped salamander, Chioglossa lusitanica. British Herpetological Society Bulletin 68: 5-6.

UIEDA, W. 2000. A review of complete albinism in bats with five new cases from Brazil. Acta Chiropterologica 2(1): 97-105.

WatKINS, L. C. 1969. Observations on the Distribution and Natural History of the Evening Bat (Nycticeius humeralis) in Northwestern Missouri and Adjacent Iowa. Transactions of the Kansas Academy of Science 72 (3): 330-336 